\title{
PROKR2 wt Allele
}

National Cancer Institute

\section{Source}

National Cancer Institute. PROKR2 wt Allele. NCI Thesaurus. Code C118610.

Human PROKR2 wild-type allele is located in the vicinity of 20p12.3 and is approximately $15 \mathrm{~kb}$ in length. This allele, which encodes prokineticin receptor 2 protein, plays a role in ligand-dependent $\mathrm{G}$ protein-coupled receptor signaling. Mutation of the gene is associated with hypogonadotropic hypogonadism 3 with or without anosmia. 